\section{Fertilizer and Plant Growth Regulator Strategies for Improving Consumer Performance of Container-grown Petunia}

\author{
Jonathan Ebba ${ }^{1}$, Ryan W. Dickson ${ }^{2}$, Paul R. Fisher ${ }^{3}$, \\ Crysta N. Harris $^{1}$, Todd Guerdat ${ }^{1}$, and Sofia Flores ${ }^{3}$
}

AdDitional Index words. floriculture, nitrogen, organic, Petunia $\times$ bybrida, postharvest, water-soluble

SuMmary. The overall goal was to evaluate fertilizer options for greenhouse producers, with or without a plant growth regulator (PGR) application, to improve subsequent performance of container-grown annuals. Petunia (Petunia $\times$ bybrida) was the model container-grown crop in simulated production and consumer environments. The first experiment at two locations (New Hampshire and Florida) compared strategies using water-soluble fertilizer [WSF $(17 \mathrm{~N}-1.8 \mathrm{P}-14.1 \mathrm{~K})$ ], controlled-release fertilizers (CRF), and slow-release fertilizers (SRF) that were either applied throughout or at the end of the 8-week production phase [point of shipping (POS)] for petunia rooted cuttings grown in 8 -inch azalea containers. In the subsequent simulated "consumer" phase, container plants were irrigated with clear water (no fertilizer) for 6 weeks. Plant performance [number of flowers, SPAD chlorophyll index, dry weight, and tissue nitrogen $(\mathrm{N})]$ at the end of the consumer phase was improved by top-dressing at POS with either CRF or granular organic fertilizer (both at $2.74 \mathrm{~g} /$ container $\mathrm{N}$ ), or preplant incorporation of either a typical $\mathrm{CRF}$ at $4.12 \mathrm{~g} /$ container $\mathrm{N}$ or a CRF with an additional prill coating to delay initial release (DCT) at $2.74 \mathrm{~g} /$ container. There was no carry-over benefit from applying a liquid urea-chain product ( 1.37 or $2.74 \mathrm{~g}$ /container $\mathrm{N}$ ) or top dressing with granular methylene di-urea $(2.74 \mathrm{~g} /$ container $\mathrm{N})$, or $400 \mathrm{mg} \cdot \mathrm{L}^{-1} \mathrm{~N}(0.2 \mathrm{~g} /$ container $\mathrm{N}$ ) from a liquid organic fertilizer at POS. The consumer benefit of applying $400 \mathrm{mg} \cdot \mathrm{L}^{-1} \mathrm{~N}(0.2 \mathrm{~g} /$ container $\mathrm{N})$ from a WSF at POS was increased by supplementing with $235 \mathrm{mg} \cdot \mathrm{L}^{-1}$ magnesium $(\mathrm{Mg})$ and $10 \mathrm{mg} \cdot \mathrm{L}^{-1}$ iron $(\mathrm{Fe})$. A second experiment in 10-inch-diameter pots evaluated the effect on consumer performance from providing 200 or $400 \mathrm{mg} \cdot \mathrm{L}^{-1} \mathrm{~N}$ of WSF with the PGR paclobutrazol, at the final $1 \mathrm{~L} /$ pot irrigation at POS. Application of $3 \mathrm{mg} \cdot \mathrm{L}^{-1}$ paclobutrazol delayed leaf yellowing and reduced plant height, width, and shoot dry weight during the consumer phase, resulting in a more compact growth habit and higher plant quality compared with plants that received no PGR, regardless of WSF treatment. Addition of supplemental $235 \mathrm{mg} \cdot \mathrm{L}^{-1} \mathrm{Mg}$ and $10 \mathrm{mg} \cdot \mathrm{L}^{-1} \mathrm{Fe}$ to the high rate of WSF and PGR did not improve consumer performance compared with other treatments that included a PGR. Overall, the first experiment demonstrated that the most effective fertilizer strategies require a CRF or SRF that will release nutrients throughout the consumer phase, and that impact of liquid fertilizer options is limited because of lower $\mathrm{N}$ supply per container. A single application at POS of a high rate of WSF with supplemental $\mathrm{Mg}$ and $\mathrm{Fe}$ may have short-term benefits, for example while plants are in a retail environment. Growers should consider combining a residual fertilizer with a PGR application for premium, value-added container annuals. consumers are unlikely to fertilize plants after sale (Oliveira et al., 2016). These strategies include a) incorporating a slowly soluble fertilizer into the root substrate before planting that continues to release nutrients after the point of sale, or b) applying a slowly or completely soluble fertilizer immediately before the point of sale. For example, Oliveira et al. (2016) showed high rates of controlled-release fertilizer (CRF) incorporated into the substrate or applied as a top-dress to the substrate surface increased plant performance [number of flowers, SPAD chlorophyll index, dry weight, and tissue nitrogen $(\mathrm{N})$ ] during a simulated consumer phase compared with plants that received only water-soluble fertilizer (WSF) during production.

Plant growth regulators (PGRs) applied during production also have carry-over effects on plant growth and habit for the consumer (Davis, 1991; Keever and Kessler, 2008; Latimer and Baden, 1994). Foliar applications of PGRs during production of a range of ornamental container crop species has been shown to suppress shoot growth during simulated shipping and retail environments as well as in the landscape (Keever and Kessler, 2008; Latimer, 1991). Chemicals such as paclobutrazol are also effective at controlling plant growth when taken up by roots (Latimer and Whipker, 2012; Ruter, 1996), and these are sometimes applied as a substrate drench or mixed with the applied fertilizer solution (Million et al., 2002).

Oliveira et al. (2016) only evaluated solid fertilizers that were either incorporated or top-dressed, rather than liquid fertilizer applications, and they did not evaluate the combined effects of increased fertilizer plus a PGR on consumer performance. Application
$\mathrm{F}$ ertilizer strategies during production of container-grown floriculture crops have carry-over effects on the performance of these plants during postharvest; and for the consumer, these methods have the potential to add value, differentiate product quality, and increase consumer success and repeat sales. Several fertilizer strategies are available to provide residual fertilizer to container-grown ornamental plants because many

\begin{tabular}{llll}
\hline $\begin{array}{l}\text { Units } \\
\begin{array}{l}\text { To convert U.S. to SI, } \\
\text { multiply by }\end{array}\end{array}$ & U.S. unit & SI unit & $\begin{array}{l}\text { To convert SI to U.S., } \\
\text { multiply by }\end{array}$ \\
\hline 29.5735 & $\mathrm{fl} \mathrm{oz}$ & $\mathrm{mL}$ & 0.0338 \\
3.7854 & $\mathrm{gal}$ & $\mathrm{L}$ & 0.2642 \\
2.54 & inch $(\mathrm{es})$ & $\mathrm{cm}$ & 0.3937 \\
25.4 & inch $(\mathrm{es})$ & $\mathrm{mm}$ & 0.0394 \\
0.5933 & lb/yard & $\mathrm{kg} \cdot \mathrm{m}^{-3}$ & 1.6856 \\
1 & $\mathrm{mmho} / \mathrm{cm}$ & $\mathrm{mS} \cdot \mathrm{cm}^{-1}$ & 1 \\
28.3495 & $\mathrm{Oz}$ & $\mathrm{g}$ & 0.0353 \\
28,350 & $\mathrm{Oz}$ & $\mathrm{mg}$ & $3.5274 \times 10^{-5}$ \\
1 & $\mathrm{ppm}$ & $\mathrm{mg} \cdot \mathrm{L}^{-1}$ & 1 \\
$\left({ }^{\circ} \mathrm{F}-32\right) \div 1.8$ & ${ }^{\circ} \mathrm{F}$ & ${ }^{\circ} \mathrm{C}$ & $\left({ }^{\circ} \mathrm{C} \times 1.8\right)+32$
\end{tabular}

Horllechnology $\cdot$ June $202131(3)$ 
immediately before the point of shipping (POS) of a high concentration of liquid forms of mineral or slow-release fertilizers may reduce labor cost compared with top-dressing solid fertilizer. Cost and labor savings are important in a highly competitive market, and a recent national grower survey (Sparks, 2020) found that labor and production cost are among the top four issues for the United States floriculture industry.

The objective of the first experiment was to compare strategies using WSF, CRF, and organic slow-release fertilizers (SRF) to provide adequate nutrition during both production and the consumer phases with containergrown petunia (Petunia $\times$ bybrida). The second objective was to evaluate the potential of irrigating with a high rate of WSF plus a PGR as the final irrigation of production and immediately before sale to suppress shoot growth and extend plant quality during a simulated retail consumer phase.

\section{Materials and methods \\ Expt. 1: Fertilizer strategies designed to provide residual nutrients for consumers}

A single-factor greenhouse experiment evaluated 12 fertilizer strategy treatments designed to provide residual nutrients during post-production with container-grown petunia. Fertilizer treatments were applied during a

Received for publication 30 Oct. 2020. Accepted for publication 22 Mar. 2021.

Published online 12 May 2021

${ }^{1}$ Department of Agriculture, Nutrition, and Food Systems, University of New Hampshire, Durham, $\mathrm{NH} 03824$

${ }^{2}$ Department of Horticulture, University of Arkansas, Fayetteville, AR 72701

${ }^{3}$ Environmental Horticulture Department, Institute of Food and Agricultural Sciences, University of Florida, Gainesville, FL 32611

We thank the U.S. Department of Agriculture-Agricultural Research Service (USDA-ARS) Floriculture and Nursery Research Initiative \#58-3607-8-725, the New Hampshire Agricultural Experiment Station, the USDA National Institute of Food and Agriculture project \#165958, and industry partners of the Floriculture Research Alliance at the University of Florida (floriculturealliance.org) for supporting this research.

We also thank Alexandra Allgeyer for data collection at the University of Florida.

R.W.D. is the corresponding author. E-mail: ryand@ uark.edu.

This is an open access article distributed under the CC BY-NC-ND license (https://creativecommons. org/licenses/by-nc-nd/4.0/).

https://doi.org/10.21273/HORTTECH04757-20 greenhouse production phase, after which plant growth and root zone nutrients were measured during a simulated consumer retail phase. Treatments differed in nutrient concentration and release pattern, whether nutrients were from inorganic or organic sources, fertilizer application as a liquid or solid, and nutrient incorporation into the growing substrate or application at the end of production. The same experiment was conducted at two locations, including the University of Florida (UF) in Gainesville (lat. 29.6516 $\mathrm{N}$, long. $82.3248^{\circ} \mathrm{W}$ ) and the University of New Hampshire (UNH) in Durham (lat. $35.9940^{\circ} \mathrm{N}$, long. $78.8986^{\circ}$ W). Each location was considered a separate experimental run-where experimental design, treatments, replicate number, data collection, and statistical analysis were identical between locations unless specified otherwise. Daily light integral and average daily air temperature were (mean $\pm \mathrm{SD}$ ) $15.7 \pm 4.6 \mathrm{~mol} \cdot \mathrm{m}^{-2} \cdot \mathrm{d}^{-1}$ and $23.5 \pm$ $1.9^{\circ} \mathrm{C}$ for the UF experimental run, and $17.8 \pm 7.8 \mathrm{~mol} \cdot \mathrm{m}^{-2} \cdot \mathrm{d}^{-1}$ and 22.8 $\pm 3.5^{\circ} \mathrm{C}$ for the $\mathrm{UNH}$ experimental run. Photosynthetic light and temperature data were measured at both locations using a portable data logger (WatchDog 2475 Plant Growth Station; Spectrum Technologies, Aurora, IL).

Table 1 summarizes the applied fertilizer treatments, designed to represent a range of strategies that could be used in commercial operations. Treatment 1 ("Control") represented a control treatment $(500 \mathrm{~mL}$ of deionized water), to simulate a grower producing a container plant with WSF and then applying no additional residual fertilizer for the consumer. The WSF was applied at $200 \mathrm{mg} \cdot \mathrm{L}^{-1} \mathrm{~N}$ with each fertigation during production, using $17.0 \mathrm{~N}-1.8 \mathrm{P}-14.1 \mathrm{~K}$ WSF (Jack's Professional LX 17-4-17 Pure Water; JR Peters, Allentown, PA).

Treatments 2 through 4 consisted of applying WSF or an organic liquid SRF at the end of the production phase (POS) at $0.2 \mathrm{~g} /$ container N. In treatment 2 ("WSF400"), a single application of the WSF was applied at $400 \mathrm{mg} \cdot \mathrm{L}^{-1} \mathrm{~N}$, intended to provide a short-term additional fertilizer application to improve consumer performance immediately after sale. In treatment 3 ("WSF400 + MgFe"), the $400 \mathrm{mg} \cdot \mathrm{L}^{-1} \mathrm{~N}$ of WSF included an additional $235 \mathrm{mg} \cdot \mathrm{L}^{-1}$ magnesium $(\mathrm{Mg})$ from magnesium sulfate $(19.9 \%$ $\mathrm{Mg}, \mathrm{JR}$ Peters) and $10 \mathrm{mg} \cdot \mathrm{L}^{-1}$ iron (Fe) chelate (Fe-EDDHA, 6.0\% Fe; AkzoNobel, Amsterdam, The Netherlands) because earlier experiments by Oliveira et al. (2016) noted symptoms of leaf chlorosis during the consumer phase consistent with $\mathrm{Mg}$ and $\mathrm{Fe}$ deficiency. In treatment 4 ("LOF"), the WSF was replaced with a complete liquid organic fertilizer using oilseed extract (Organic Plant Food 3N-0.4P$0.8 \mathrm{~K}$; Nature's Source, Sherman, TX) at $400 \mathrm{mg} \cdot \mathrm{L}^{-1} \mathrm{~N}$. All fertilizer solutions were mixed using deionized water. Control and fertilizer treatment solutions were applied at $500 \mathrm{~mL}$ per container.

Treatments 5 through 9 represented applications of CRF or SRF as a top dress at the POS. In treatment 5 ("CRF TD") $18.3 \mathrm{~g}$ of CRF (Osmocote Plus $15 \mathrm{~N}-3.9 \mathrm{P}-10.0 \mathrm{~K}$; Everris, Geldermalson, The Netherlands) was applied per container. The resulting $2.74 \mathrm{~g} \mathrm{~N}$ per container (the high label rate) was used to standardize $\mathrm{N}$ application for treatments 6 to 9. For treatment 6 ("LU"), UF used a liquid ureachain product (N-Sure $28 \mathrm{~N}-0 \mathrm{P}-0 \mathrm{~K}$; Tessenderlo Kerly, Phoenix, AZ); and in Treatment 7 ("LU + MgFe"), additional $\mathrm{Mg}$ and $\mathrm{Fe}$ were added to the $\mathrm{N}$ Sure because these nutrients were absent in $\mathrm{N}$-Sure. The $\mathrm{N}$ concentration for treatments 6 and 7 was decreased by half at UNH because leaf marginal burn was noted with these treatments at UF. Treatment 8 ("MDU TD") was a solid slow-release product, methylene di-urea, at $6.9 \mathrm{~g}$ per container (Nutralene 40N-0P-0K; Agrium Advanced Technologies, Loveland, $\mathrm{CO}$ ). Treatment 9 ("SUS TD") was an organic slow-release fertilizer based on composted poultry litter at $34.3 \mathrm{~g}$ per container (Sustane 8N-1.8P-3.3K, Sustane Natural Fertilizers, Cannon Falls, $\mathrm{MN})$. Treatments 5 through 9 were applied at the same time, at the final irrigation of production $(500 \mathrm{~mL}$ of deionized water).

In treatments 10 through 12 , CRF was incorporated into the growing substrate before the start of production. Treatment 10 ("CRF high") incorporated the same type and rate of CRF as top-dressed in Treatment 5 (18.3 g per container, equivalent to $12.3 \mathrm{lb} /$ yard $^{3}$ substrate). In treatment 11 ("CRF very high"), the CRF 


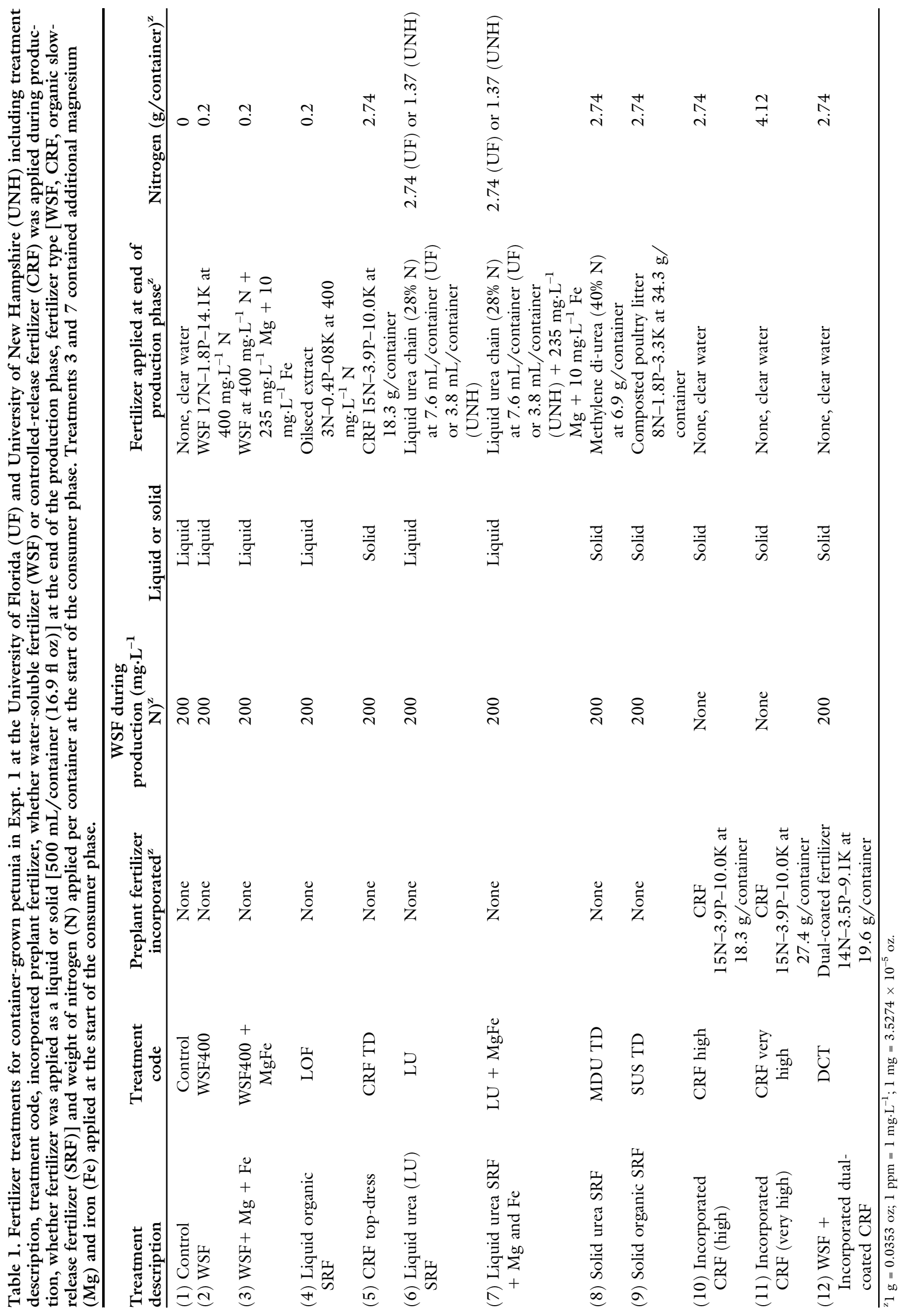


incorporation rate was increased to $27.4 \mathrm{~g}$ per container (equivalent to $18.5 \mathrm{lb} /$ yard $^{3}$ substrate). In treatment 12 ("DCT"), a dual-coated fertilizer was used, with a waxy coating that covered an inner CRF prill (Protect 14N-3.5P-9.1K, Everris) incorporated at $19.6 \mathrm{~g}$ per container $(13.1 \mathrm{lb} /$ $\operatorname{yard}^{3}$ ) of substrate. Incorporated CRF (treatments 10 and 11) were intended to provide nutrients during both production and consumer phases, whereas incorporated DCT (treatment 12) was intended to provide nutrients primarily during the consumer phase. Treatments 10 through 12 received $500 \mathrm{~mL}$ of deionized water as the final irrigation of production.

Vegetatively propagated cuttings of 'Supertunia Vista Bubblegum' petunia were sourced from a commercial propagator (Pleasant View Gardens, Louden, NH) and transplanted from 128-cell trays into 8-inch-diameter plastic azalea containers (Poppelmann Plastics US, Claremont, NC) in soilless peat-based substrate (ProMix BX; Premier Tech, Quakertown, PA) at one plant per container. Controlled-release fertilizer and DCT for treatments 10 through 12 were incorporated into the substrate before transplant (Table 1). Each container represented one treatment replicate. Eight replicates per fertilizer treatment were arranged on eight greenhouse benches using a randomized complete block design, where one bench served as one experimental block.

The production phase began at transplant, which occurred on 15 Feb. 2017 and 5 May 2017 for UF and UNH, respectively. Treatments with incorporated CRF (treatments 10 and 11) were irrigated with $500 \mathrm{~mL}$ deionized water at transplant and at each subsequent irrigation event during production. Treatments 1 through 9 and treatment 12 were fertilized at transplant and at each subsequent irrigation event with $500 \mathrm{~mL}$ of WSF at $200 \mathrm{mg} \cdot \mathrm{L}^{-1} \mathrm{~N}$. All treatments were irrigated uniformly once substrate moisture dried to $\approx 50 \%$ maximum waterholding capacity. Plastic saucers placed under each container collected any leachate after irrigation and allowed for reabsorption into the substrate.

The production phase ended on 29 Mar. 2017 and 15 June 2017 for UF and UNH experimental runs (42 or $4 \mathrm{l} \mathrm{d}$ after transplant, respectively), at which point residual fertilizers were applied for treatments 1 through 9 (Table 1). After production, plants remained in the same greenhouse an additional 56 and $61 \mathrm{~d}$ at UF and UNH, respectively, for a simulated retail consumer phase. During the consumer phase, plants were irrigated only with deionized water (no fertilizer nutrients), following the irrigation methods described for production. Deionized water was used because high alkalinity in tap water can raise substrate $\mathrm{pH}$ and induce micronutrient deficiencies with petunia, particularly iron and manganese (Fisher, 2003).

Twelve additional container replicates grown for the control (treatment 1), CRF high (treatment 10), CRF very high (treatment 11 ), and DCT (treatment 12) fertilizer treatments were destructively sampled at the end of production for initial data collection. Initial data were not collected for treatments 2 through 9 , because these fertilizer strategies were applied at the end of production, and plant growth and substrate nutrients would have been like the Control treatment.

Substrate $\mathrm{pH}$ and electrical conductivity (EC) were measured for each replicate using a pour-through method with a benchtop $\mathrm{pH} / \mathrm{EC}$ meter (Orion Dual Star; Thermo Fisher Scientific, Waltham, MA). Leachate samples $(20 \mathrm{~mL})$ were analyzed for ammonium-N $\left(\mathrm{NH}_{4}-\mathrm{N}\right)$ and nitrate$\mathrm{N}\left(\mathrm{NO}_{3}-\mathrm{N}\right)$ concentrations using automated and semiautomated colorimetry (University of Florida Soil Testing Laboratory, Gainesville, FL; University of Maine Plant and Soil Laboratory, Augusta, ME), and $\mathrm{N}$ forms were summed for total $\mathrm{N}$ concentration.

Leaf greenness was measured using a portable SPAD chlorophyll index meter (Minolta leaf SPAD meter; Spectrum Technologies, Aurora, IL). Each replicate value was the average of five leaf SPAD chlorophyll measurements taken on recently mature leaves from randomly selected shoots per plant. Flower number was measured as total open flowers per replicate.

Shoot dry weight per replicate was measured by cutting plant stems directly above the substrate surface and oven-drying shoot tissue at $70^{\circ} \mathrm{C}$ for $48 \mathrm{~h}$. Shoot tissue was rinsed with dilute hydrochloric acid $(\mathrm{HCl})$ followed by deionized water before being oven-dried to remove potential residues on leaf surfaces. Dry shoot tissue was ground and passed through a 0.017 -inch sieve, and percent $\mathrm{N}$ was measured using the Purcell and King (1996) persulfate digestion method (Quality Analytical Laboratories, Panama City, FL).

Final data collection for all treatments occurred at the end of the consumer phase on 24 May 2017 and 15 Aug. 2017 (56 and 61 d after POS) for UF and UNH experimental runs, respectively. Substrate $\mathrm{pH}$ and $\mathrm{EC}$, leaf SPAD chlorophyll index, flower number, shoot dry mass, and percent $\mathrm{N}$ were measured for each replicate as described for initial data collection at the end of production. Total accumulation of $\mathrm{N}$ in shoot tissue was calculated by multiplying the percentage of $\mathrm{N}$ in the dry shoot tissue by the total dry shoot tissue weight per replicate at the end of the consumer phase.

Data were analyzed separately for UF and UNH experimental runs. Analysis of variance with PROC GLIMMIX in SAS (version 9.4; SAS Institute, Cary, NC) was used to evaluate fertilizer strategy effects on substrate $\mathrm{pH}$ and EC, plant height and width, leaf SPAD chlorophyll index, flower number, substrate $\mathrm{N}$ concentration, shoot dry weight, percent $\mathrm{N}$ in dry shoot tissue, and total shoot $\mathrm{N}$ per plant separately for the end of production and end of consumer phases. Mean separation used Tukey's honestly significant difference (HSD) at $\alpha=0.05$.

\section{Expt. 2: Irrigation with water- soluble fertilizer and plant growth regulator at the end of production}

A greenhouse experiment evaluated WSF level with and without paclobutrazol at 0 and $3 \mathrm{mg} \cdot \mathrm{L}^{-1}$ as a final 1L substrate drench application at POS on 7 Apr. 2018. The five treatments consisted of $200 \mathrm{mg} \cdot \mathrm{L}^{-1} \mathrm{~N}$ without paclobutrazol ("WSF"), $400 \mathrm{mg} \cdot \mathrm{L}^{-1}$ $\mathrm{N}$ without paclobutrazol ("WSF400"), $200 \mathrm{mg} \cdot \mathrm{L}^{-1} \mathrm{~N}$ plus $3 \mathrm{mg} \cdot \mathrm{L}^{-1}$ paclobutrazol ("WSF + PGR"), $400 \mathrm{mg} \cdot \mathrm{L}^{-1} \mathrm{~N}$ plus $3 \mathrm{mg} \cdot \mathrm{L}^{-1}$ paclobutrazol ("WSF400 + PGR"), and the WSF400 + PGR treatment with supplemental $235 \mathrm{mg} \cdot \mathrm{L}^{-1}$ $\mathrm{Mg}$ and $10 \mathrm{mg} \cdot \mathrm{L}^{-1} \mathrm{Fe}$ ("WSF400+ $\mathrm{Mg}+\mathrm{Fe}+$ PGR"). Petunia were grown in 10-inch-diameter hanging baskets at the same UNH greenhouse location in Expt. 1. Hanging baskets were 
used in this experiment because petunia are commonly grown commercially in baskets, and hanging baskets are expected to last for relatively long periods by consumers and may therefore benefit from residual fertilizer and PGR strategies. The experiment started at the end of the production period with the application of WSF and PGR treatments, after which the consumer phase started and root zone nutrients and plant performance were monitored. Daily light integral and average daily air temperature during the consumer phase were (mean \pm SD) $23.3 \pm 9.1 \mathrm{~mol} \cdot \mathrm{m}^{-2} \cdot \mathrm{d}^{-1}$ and $21.5 \pm$ $1.7^{\circ} \mathrm{C}$, respectively.

Unrooted cuttings of petunia 'Supertunia Vista Bubblegum' from Pleasant View Gardens were vegetatively propagated at UNH in 128-cell trays containing the same soilless substrate used in Expt. 1. Rooted transp lants were transferred into 10 -inch-diameter plastic hanging basket containers (Poppelmann Plastics US) at one plant per container on 25 May 2017. Plants were fertilized at each irrigation using the same water-soluble fertilizer and irrigation methods described in Expt. 1 at $200 \mathrm{mg} \cdot \mathrm{L}^{-1} \mathrm{~N}$.

Treatments were formulated with the same WSF used during production and commercially available paclobutrazol (Bonzi; Syngenta Crop Protection, Greensboro, NC). Each replicate consisted of one container, with five replicates per treatment. Replicates were placed on top of mesh greenhouse benches following a randomized complete block design immediately after the application of treatments on 1 Aug. 2017, and these were irrigated as previously described for production using only deionized water (no fertilizer nutrients).

Root zone nutrients and plant performance data were measured as substrate $\mathrm{pH}$ and $\mathrm{EC}$, substrate $\mathrm{N}$, and leaf SPAD chlorophyll index collected for each replicate at $1,7,21$, 35,49 , and $63 \mathrm{~d}$ after treatment application, as well as flower number, shoot dry weight, percent shoot tissue $\mathrm{N}$, and total accumulated $\mathrm{N}$ at $63 \mathrm{~d}$ (end of consumer phase). Data collected for these parameters followed methods described in Expt. 1. Plant dimensions were also measured as greatest height (centimeters) from the substrate surface and greatest width (centimeters) of the canopy per replicate at $1,7,21,35,49$, and $63 \mathrm{~d}$ after treatment application.

Analysis of variance with PROC GLM in SAS (version 9.4) was used to evaluate treatment effects on substrate $\mathrm{pH}$ and $\mathrm{EC}$, substrate $\mathrm{N}$, shoot dry weight, plant height and width, leaf SPAD chlorophyll index, flower number, and percent and accumulated $\mathrm{N}$ in shoot tissue during the consumer phase. Mean separation used Tukey's HSD at $\alpha=0.05$.

\section{Results and discussion \\ Expt. 1: Fertilizer strategies designed to provide residual nutrients for consumers}

END OF PRODUCTION. All four fertilizer strategies (which included WSF only, incorporated CRF at high or very high rates, or incorporated DCT with WSF) produced commercially acceptable plants during the production phase. There were no fertilizer effects on petunia shoot dry weight or flower number at UF or UNH (Table 2). Most substrate $\mathrm{pH}$ values were within or slightly above the recommended range for petunia $[\mathrm{pH} 5.4$ to 6.2 (Fisher, 2003)], and there were no visual symptoms of iron deficiency or large differences in leaf SPAD chlorophyll index (Table 2). Substrate EC and $\mathrm{N}$ concentrations were higher than recommended for petunia and general bedding plants using a pourthrough method [EC 1.3 to 2.0 $\mathrm{mS} \cdot \mathrm{cm}^{-1}$ (Gibson et al., 2007), leachate $\mathrm{NO}_{3}-\mathrm{N}$ between 100 to 199 $\mathrm{mg} \cdot \mathrm{L}^{-1} \mathrm{~N}$ (Nelson, 2011)] for Control and DCT-treated plants at UF and with all treatments at $\mathrm{UNH}$ ( Table 2). The high EC likely resulted from excess fertilizer supply combined with no leaching, however there were no signs of high soluble salt stress at either location. All fertilizer treatments produced petunia that appeared healthy, with adequate SPAD chlorophyll index values and flower number at the end of production.

END OF CONSUMER PHASE. Substrate $\mathrm{pH}$ at the end of the consumer phase was above recommended values for petunia $[\mathrm{pH} 5.4$ to 6.2 (Fisher, 2003)] at both locations - with the exception of CRF very high at UF (Tables 3 and 4), which remained near the upper recommended $\mathrm{pH}$ limit. At $\mathrm{UF}$, substrate EC averaged $1.6 \mathrm{mS} \cdot \mathrm{cm}^{-1}$ and was not influenced by fertilizer treatment (data not shown), which was within the range suggested for petunia by Gibson et al. (2007). In contrast, EC levels dropped considerably during the consumer phase at UNH with all treatments to below the recommended $1.3 \mathrm{mS} \cdot \mathrm{cm}^{-1}$, with the exception of CRF TD with a final substrate EC of $1.52 \mathrm{mS} \cdot \mathrm{cm}^{-1}$ (Table 4).

In contrast to the dark-green foliage and initial SPAD value above 40 at the end of the production phase (Table 2), chlorosis was severe and decreased to below 30 for Control plants at both locations (Tables 3 and 4). Leaf SPAD was affected by fertilizer treatment at both UF and UNH [ $P$ $\leq 0.0001]$. The highest SPAD levels occurred in plants receiving the topdressed CRF TD and SUS TD treatments at UF and UNH, and also for incorporated treatments CRF very high and DCT at UF.

The high rate of WSF plus supplemental $\mathrm{Mg}$ and Fe resulted in a moderate effect on plant performance during the consumer phase compared with the Control. Plants receiving the WSF400 + MgFe treatment had higher SPAD and flower number than Control plants at UNH at the end of the consumer phase (Table 4), but there was no effect of the WSF400 treatment alone. At UF, there was no difference in SPAD or flower number between the control plants vs. those receiving WSF400 or WSF400 + $\mathrm{MgFe}$ treatments at the end of the consumer phase (Table 3). However, there was a short-term effect at UF whereby at week 2 the plants receiving WSF400 + MgFe had a higher SPAD value (47.8) than the Control [41.8 $(P<0.01)]$

Other liquid fertilizer treatments ( $\mathrm{LOF}, \mathrm{LU}, \mathrm{LU}+\mathrm{MgFe}$ ) also provided limited improvement to plant performance during the consumer phase. Liquid fertilizer treatments LOF and $\mathrm{LU}+\mathrm{MgFe}$ had greater SPAD chlorophyll index compared with the Control at UNH (Table 4), but these had no effect on SPAD at UF. Plants receiving the $\mathrm{LU}$ or $\mathrm{LU}+\mathrm{MgFe}$ treatments exhibited phytotoxicity (marginal leaf burn) and stunted plant growth [lower shoot dry mass and flower number (Table 3)] at UF with the $2.74 \mathrm{~g} /$ container $\mathrm{N}$ rate of LU, and the LU concentration was therefore reduced by half at $\mathrm{UNH}$. 


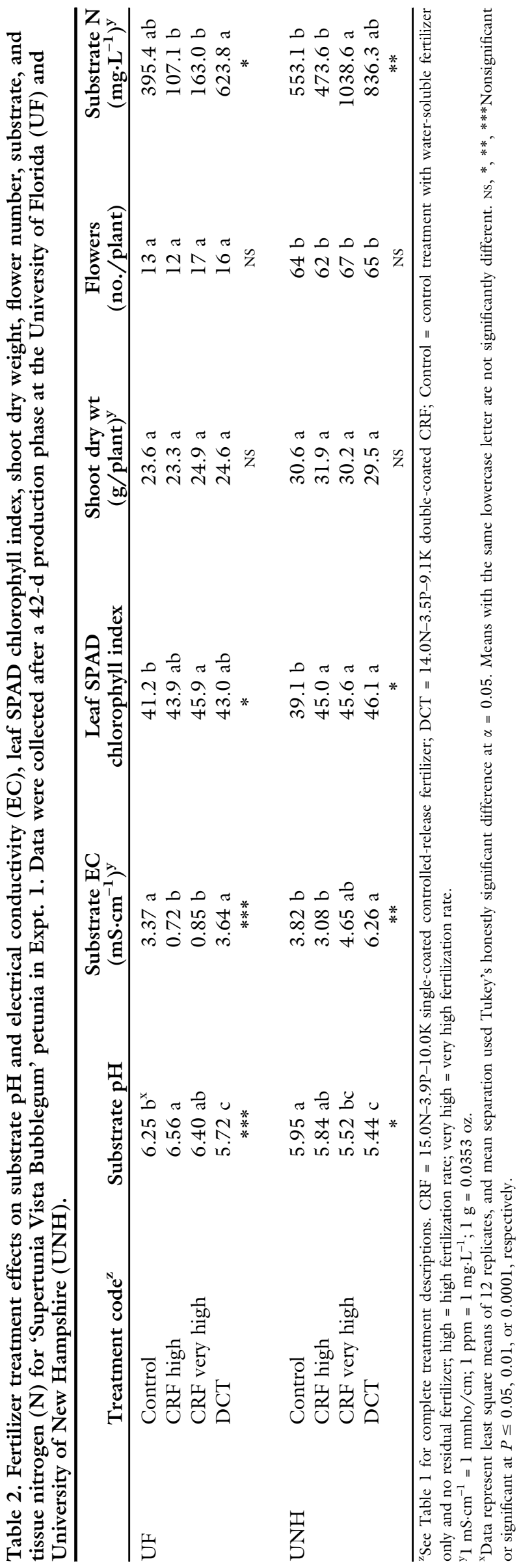

Fertilizer treatments affected shoot dry weight and flower number at the end of the consumer phase $[P$ $\leq 0.0001$ (Tables 3 and 4)]. Shoot dry weight per plant was greatest for treatments CRF TD (treatment 5) and SUS TD (treatment 9) as well as for the incorporated treatment DCT (treatment 12) at both UF and UNH (Tables 3 and 4). Trends in flower number per plant were like those observed for shoot dry weight (Tables 3 and 4), where greater shoot dry weight appeared correlated with greater flower number. The WSF400 $+\mathrm{MgFe}$ and CRF very high also increased flowering compared with the Control at UNH only (Table 4).

Substrate $\mathrm{N}$ differed among treatments at the end of the consumer phase at $\mathrm{UNH}[P \leq 0.0001$ (Table 4 )], where $\mathrm{N}$ was greatest for $\mathrm{CRF}$ TD and lowest for CRF high, CRF very high, and DCT. At UF, substrate $\mathrm{N}$ did not differ between treatments (data not shown).

Percent shoot tissue $\mathrm{N}$ also differed between treatments at both locations $[P \leq 0.0001$ (Tables 3 and 4 )], with shoot tissue $\mathrm{N}$ mainly below the sufficiency range recommended for dried petunia leaves $[3.85 \%$ to 7.60\% N (Mills and Jones, 1996)]. Shoot tissue $\mathrm{N}$ was within the sufficiency range for plants receiving LU and $\mathrm{LU}+\mathrm{MgFe}$ at $\mathrm{UF}$, but this result was probably because of less dilution of $\mathrm{N}$ concentration in plants that had low shoot dry mass.

Nitrogen accumulation in shoot tissue was greater than the control for CRF TD (treatment 5), MDU TD (treatment 9), SUS TD (treatment 9), and DCT (treatment 12) at UF (Fig. IA), and for CRF TD (treatment 5), SUS TD (treatment 9), and DCT (treatment 12) at UNH (Fig. 1B). In comparison with the nitrogen uptake of 676 (CRF high) to 2263 (CRF TD) $\mathrm{mg} /$ container N (Fig. 1B), fertilizer treatments 2 to 4 only provided $200 \mathrm{mg} /$ container $\mathrm{N}$ whereas treatments 5 to 12 contributed at least $1370 \mathrm{mg} /$ container N (Table $\mathrm{l}$ ). Water-soluble fertilizers and LOF applied at the POS therefore did not provide sufficient $\mathrm{N}$ to maintain plant performance/quality [flower number, shoot dry weight, SPAD chlorophyll index, and shoot tissue $\mathrm{N}$ ] for the duration of the consumer phase [56 and $61 \mathrm{~d}$ at UF and UNH, respectively (Tables 
3 and 4$)]$. However, the additional $117.5 \mathrm{mg} /$ container $\mathrm{Mg}$ and $5 \mathrm{mg} /$ container Fe provided by the WSF400 $+\mathrm{MgFe}$ treatment did improve leaf SPAD chlorophyll index and flower number compared with WSF400 alone in the UNH experiment (Table 4 ), emphasizing the roles of $\mathrm{Mg}$ and $\mathrm{Fe}$ in addition to $\mathrm{N}$ in terms of plant quality. Compared with the WSF400, the WSF400 + MgFe treatment resulted in an additional $164.8 \mathrm{mg} /$ plant $\mathrm{Mg}$ and $6.8 \mathrm{mg} /$ plant $\mathrm{Fe}$ (data not shown), like the extra $\mathrm{Mg}$ and $\mathrm{Fe}$ supplied by WSF400 + MgFe at the start of the consumer phase.

A top-dress of CRF and SLF treatments (treatments 5 through 9) provided up to $2.7 \mathrm{~g}$ additional $\mathrm{N}$ per container when applied at the end of production, but only CRF TD and SUS TD consistently produced high-quality petunia for the consumer at both locations (Tables 3 and 4). The controlledrelease fertilizer (CRF TD) and composted poultry litter (SUS TD) top-dress fertilizers were marketed as having nutrient release periods of $\approx 120$ and $45 \mathrm{~d}$, respectively, and provided a longer-lasting supply of nutrients during the consumer phase as indicated by the high plant uptake of $\mathrm{N}$ in Fig. 1. At UF, a top-dress with methylene di-urea (MDU TD) also resulted in relatively high shoot $\mathrm{N}$ accumulation during the consumer phase
(Fig. 1A), but plants had SPAD chlorophyll index, shoot weight, and flower number like the control (treatment $\mathrm{l}$ ) in Table 3. The methylene di-urea (MDU TD) treatment only supplied $\mathrm{N}$, and the overall poor plant performance may have resulted from the lack of other essential plant nutrients.

Differences in plant performance between CRF and slow-release organic fertilizer treatments may have resulted from differences in nutrient release over time. Nitrogen release for CRF is influenced mainly by the coating technology and temperature (Broschat and Moore, 2007; Cabrera, 1997; Carson and Ozores-Hampton, 2012; Oliveira et al., 2016), where a temperature of $21^{\circ} \mathrm{C}$ is usually used to rate CRF longevity (Oliveira et al., 2016). Nitrogen release from organic SRFs is influenced by several factors, including soil type, temperature, microbial activity, and type of organic fertilizer material (Burnett et al., 2016; Fan and Li, 2010; Guertal, 2009; Li and Mattson, 2019), and nitrogen release can vary substantially between fertilizer sources and environmental conditions.

Previous research on residual fertilizer strategies by Oliveira et al. (2016) found that container-grown petunia that received CRF were of the highest quality and still growing vigorously after $42 \mathrm{~d}$ in the consumer phase, especially with CRF (incorporated or top-dressed) or DCT applied at a high rate. In this study, CRF and DCT treatments (treatments 5, 10, 11 , and 12), as well as top-dressing with composted poultry litter (SUS $\mathrm{TD}$, treatment 6 ), also resulted in the most actively growing and healthy plants by the end of the consumer phase at both experimental locations. Incorporation or top-dress with a CRF product is a practical and reliable method of supplying residual nutrients for the consumer. Use of organic SRF may also be effectiveprovided these products provide a favorable nutrient release and do not overly increase substrate $\mathrm{pH}$ during nitrogen mineralization.

\section{Expt. 2: Irrigation with water- soluble fertilizer and plant growth regulator at the end of production}

During the consumer phase, substrate $\mathrm{pH}$ at the start of the consumer phase was within the recommended range for petunia [pH 5.4 to 6.2 (Fisher, 2003)] and increased over time, but it was not influenced by fertilizer or PGR strategy (data not shown). At day 1 of the consumer phase, substrate EC and $\mathrm{N}$ were greater with all treatments that included a high rate of WSF at $400 \mathrm{mg} \cdot \mathrm{L}^{-1} \mathrm{~N}$ (WSF400 and WSF400

Table 3. Residual fertilizer treatment effects on substrate pH, leaf SPAD chlorophyll index, shoot dry weight, flower number, substrate, and tissue nitrogen $(\mathrm{N})$ at the end of consumer phase for 'Supertunia Vista Bubblegum' petunia in Expt. 1 at University of Florida.

\begin{tabular}{|c|c|c|c|c|c|}
\hline Treatment code ${ }^{\mathrm{z}}$ & Substrate $\mathrm{pH}$ & $\begin{array}{c}\text { Leaf SPAD } \\
\text { chlorophyll index }\end{array}$ & $\begin{array}{l}\text { Shoot dry wt } \\
(\mathrm{g} / \text { plant })^{\mathrm{y}}\end{array}$ & $\begin{array}{c}\text { Flowers } \\
\text { (no./plant) }\end{array}$ & $\begin{array}{c}\text { Tissue } \mathrm{N} \\
(\%)\end{array}$ \\
\hline Control & $6.95 \mathrm{a}^{\mathrm{x}}$ & $28.9 \mathrm{~cd}$ & $65.0 \mathrm{~cd}$ & $131 \mathrm{bc}$ & $1.71 \mathrm{c}$ \\
\hline WSF400 & $6.99 \mathrm{a}$ & $29.4 \mathrm{~cd}$ & 72.9 abc & $162 \mathrm{ab}$ & $1.72 \mathrm{c}$ \\
\hline WSF400 $+\mathrm{MgFe}$ & $7.01 \mathrm{a}$ & $30.6 \mathrm{bcd}$ & $73.9 \mathrm{abc}$ & $140 \mathrm{bc}$ & $1.98 \mathrm{bc}$ \\
\hline $\mathrm{LOF}$ & $7.04 \mathrm{a}$ & $29.3 \mathrm{~cd}$ & $67.7 \mathrm{bc}$ & $140 \mathrm{bc}$ & $1.89 \mathrm{c}$ \\
\hline CRF TD & $6.92 \mathrm{a}$ & $38.5 \mathrm{ab}$ & $79.3 \mathrm{ab}$ & $206 \mathrm{a}$ & $2.87 \mathrm{bc}$ \\
\hline MDU TD & $6.99 \mathrm{a}$ & $27.9 \mathrm{~d}$ & $68.1 \mathrm{bc}$ & $137 \mathrm{bc}$ & $3.17 \mathrm{~b}$ \\
\hline SUS TD & $7.03 \mathrm{a}$ & $38.8 \mathrm{ab}$ & $82.8 \mathrm{a}$ & $173 \mathrm{ab}$ & $2.52 \mathrm{bc}$ \\
\hline CRF high & $6.39 \mathrm{bc}$ & $36.2 \mathrm{abcd}$ & $51.2 \mathrm{de}$ & $153 \mathrm{ab}$ & $2.07 \mathrm{bc}$ \\
\hline CRF very high & $6.21 \mathrm{c}$ & $38.5 \mathrm{ab}$ & $66.6 \mathrm{bc}$ & $161 \mathrm{ab}$ & $2.58 \mathrm{bc}$ \\
\hline DCT & $\begin{array}{c}6.54 \mathrm{~b} \\
* * *\end{array}$ & $\begin{array}{r}41.1 \mathrm{a} \\
* * *\end{array}$ & $\begin{array}{r}82.7 \text { a } \\
* * *\end{array}$ & $\begin{array}{c}212 \mathrm{a} \\
* * *\end{array}$ & $\begin{array}{c}2.71 \mathrm{bc} \\
* * *\end{array}$ \\
\hline
\end{tabular}

${ }^{\mathrm{z}}$ See Table 1 for complete treatment descriptions. CRF $=15.0 \mathrm{~N}-3.9 \mathrm{P}-10.0 \mathrm{~K}$ single-coated controlled-release fertilizer; DCT $=14.0 \mathrm{~N}-3.5 \mathrm{P}-9.1 \mathrm{~K}$ double-coated CRF;

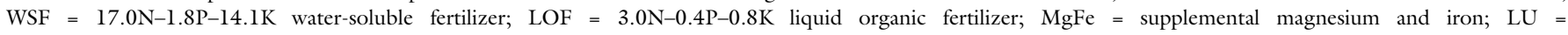
$28.0 \mathrm{~N}-0.0 \mathrm{P}-0.0 \mathrm{~K}$ liquid urea; $\mathrm{MDU}=40.0 \mathrm{~N}-0.0 \mathrm{P}-0.0 \mathrm{~K}$ methylene di-urea; $\mathrm{SUS}=8.0 \mathrm{~N}-1.8 \mathrm{P}-3.3 \mathrm{~K}$ composted poultry litter; DCT $=14.0 \mathrm{~N}-3.5 \mathrm{P}-0.8 \mathrm{~K} ; \mathrm{TD}=$ topdressed fertilizer; high $=$ high fertilization rate; very high $=$ very high fertilization rate.

${ }^{\mathrm{y}} \mathrm{l} \mathrm{g}=0.0353 \mathrm{oz}$.

${ }^{\mathrm{x}}$ Data represent least square means of eight replicates, and mean separation used Tukey's honestly significant difference at $\alpha=0.05$. Means with the same lowercase letter are not significantly different. ***Significant at $P \leq 0.0001$ 


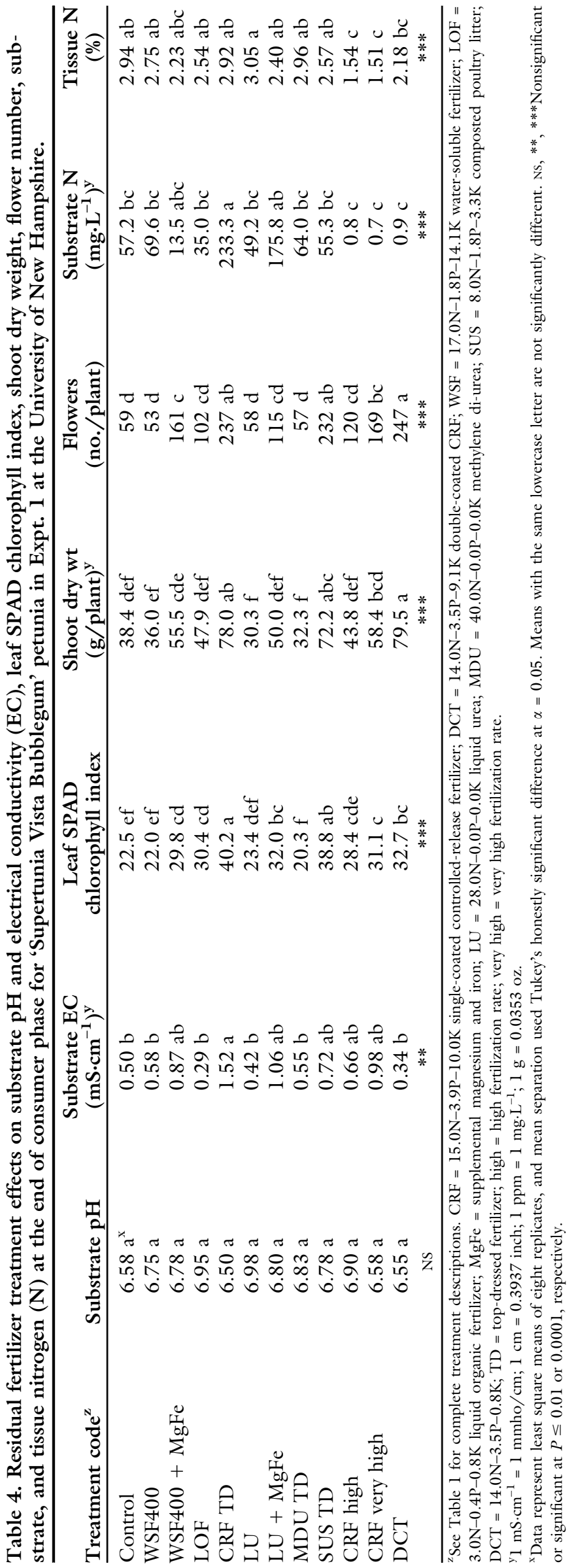

+ PGR or WSF400 $+\mathrm{Mg}+\mathrm{Fe}$ + PGR) compared with the WSF or WSF + PGR treatments $[P<0.05$ (Figs. 2A and B)]. However, this difference was short term, and there were no differences in substrate $\mathrm{EC}$ or $\mathrm{N}$ between fertilizer and PGR strategies for the remainder of the experiment. Substrate EC was below the recommended range for petunia [EC of 1.3 to 2.0 $\mathrm{mS} \cdot \mathrm{cm}^{-1}$ (Gibson et al., 2007)] at $7 \mathrm{~d}$ into the consumer phase, and an EC of near zero by $21 \mathrm{~d}$ indicated depletion of root zone nutrients.
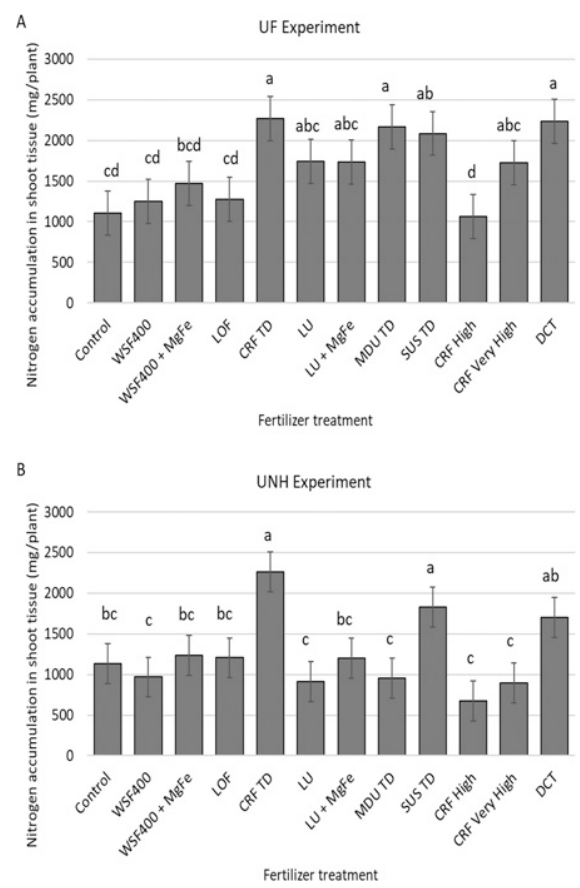

Fig. 1. Effect of residual fertilizer strategy on accumulated nitrogen $(\mathrm{N})$ in shoot tissue of 'Supertunia Vista

Bubblegum' petunia at the end of the consumer phase for the University of Florida (UF) and University of New Hampshire (UNH). Data represent eight replicates per treatment, and error bars represent $95 \%$ confidence intervals based on Tukey's honestly significant difference at $\alpha=0.05$; $\mathrm{CRF}=$ $15.0 \mathrm{~N}-3.9 \mathrm{P}-10.0 \mathrm{~K}$ single-coated controlled-release fertilizer; DCT = 14.0N-3.5P-9.1 K double-coated CRF; $\mathrm{WSF}=17.0 \mathrm{~N}-1.8 \mathrm{P}-14.1 \mathrm{~K}$ watersoluble fertilizer; $\mathrm{LOF}=3.0 \mathrm{~N}-$ $0.4 \mathrm{P}-0.8 \mathrm{~K}$ liquid organic fertilizer; $\mathrm{MgFe}=$ supplemental magnesium and iron; liquid urea $(\mathrm{LU})=28.0 \mathrm{~N}-0.0 \mathrm{P}-$ $0.0 \mathrm{~K} \mathrm{LU} ; \mathrm{MDU}=40.0 \mathrm{~N}-0.0 \mathrm{P}-0.0 \mathrm{~K}$ methylene di-urea; SUS $=8.0 \mathrm{~N}-$ 1.8P-3.3K composted poultry litter; DCT $=14.0 \mathrm{~N}-3.5 \mathrm{P}-0.8 \mathrm{~K} ; \mathrm{TD}=$ topdressed fertilizer; high $=$ high fertilization rate; very high $=$ very high fertilization rate; $1 \mathrm{mg}=3.5274 \times 10^{-5} \mathrm{oz}$. 
Applying the PGR paclobutrazol, but not a high rate of WSF at 400 $\mathrm{mg} \cdot \mathrm{L}^{-1} \mathrm{~N}$, at the final irrigation of production affected SPAD, plant canopy height, and canopy width during the consumer phase $[P \leq 0.05$ (Fig. $3)$ ]. Adding additional $\mathrm{Mg}$ and $\mathrm{Fe}$ did not increase SPAD compared with WSF400 + PGR alone. Leaf SPAD chlorophyll index remained at relatively high levels across fertilizer and PGR strategies until $21 \mathrm{~d}$ into the consumer phase (Fig. 3A), after which SPAD index values decreased. Regardless of fertilizer treatment, irrigating with $3 \mathrm{mg} \cdot \mathrm{L}^{-1}$ paclobutrazol at POS resulted in a lower rate of
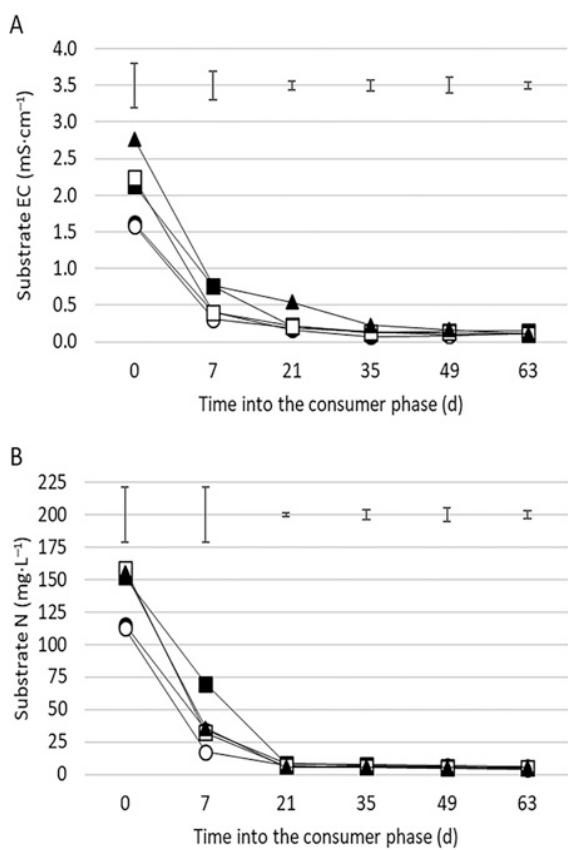

Fig. 2. Effect of water-soluble fertilizer [WSF (17.0N-1.8P-14.1K)] and plant growth regulator (PGR) treatments applied as the last irrigation during production on substrate electrical conductivity [EC (A)] and nitrogen [N (B)] during the consumer phase for 'Supertunia Vista Bubblegum' petunia. Symbols represent the mean of five replicate plants per fertilizer and PGR treatment. Circle and square symbols represent WSF applied at 200 and $\mathbf{4 0 0}$ $\mathrm{mg} \cdot \mathrm{L}^{-1} \mathrm{~N}$, respectively. Closed and open symbols represent PGR applied at 0 and $3 \mathrm{mg} \cdot \mathrm{L}^{-1}$ paclobutrazol, respectively. Closed triangle symbols represent WSF at $400 \mathrm{mg} \cdot \mathrm{L}^{-1} \mathrm{~N}, 3 \mathrm{mg} \cdot \mathrm{L}^{-1}$ paclobutrazol, and $235 \mathrm{mg} \cdot \mathrm{L}^{-1}$ magnesium and 10 $\mathrm{mg} \cdot \mathrm{L}^{-1}$ iron. Error bars represent $95 \%$ confidence intervals based on Tukey's honestly significant difference at $\alpha=0.05$ analyzed by date; $1 \mathrm{ppm}=1 \mathrm{mg} \cdot \mathrm{L}^{-1} ; 1$ $\mathrm{mS} \cdot \mathrm{cm}^{-1}=1 \mathrm{mmho} / \mathrm{cm}$. decreasing SPAD chlorophyll index and delayed symptoms of leaf chlorosis and yellowing by $\approx 7 \mathrm{~d}$ (Fig. 3A), which were visually observed when SPAD values dropped below 30 .

Plant canopy height was similar across strategies until $35 \mathrm{~d}$ into the consumer phase, after which canopy height remained slightly lower for plants receiving PGR compared with

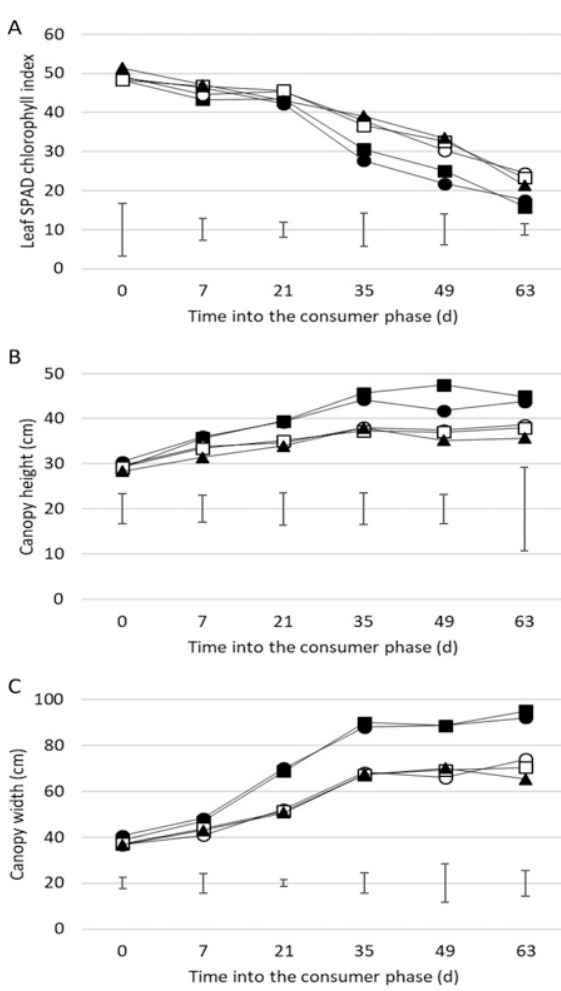

Fig. 3. Effect of water-soluble fertilizer [WSF (17.0N-1.8P-14.1K)] and plant growth regulator (PGR) treatments applied as the last irrigation during production on leaf SPAD chlorophyll index (A), canopy height (B), and canopy width $(\mathrm{C})$ during the consumer phase for 'Supertunia Vista

Bubblegum' petunia. Symbols represent the mean of five replicate plants per fertilizer and PGR treatment. Circle and square symbols represent WSF applied at 200 and 400 $\mathrm{mg} \cdot \mathrm{L}^{-1}$ nitrogen, respectively. Closed and open symbols represent PGR applied at 0 and $3 \mathrm{mg} \cdot \mathrm{L}^{-1}$

paclobutrazol, respectively. Closed and open symbols represent PGR applied at 0 and $3 \mathrm{mg} \cdot \mathrm{L}^{-1}$ paclobutrazol, respectively. Closed triangle symbols represent WSF at $400 \mathrm{mg} \cdot \mathrm{L}^{-1} \mathrm{~N}, 3$ $\mathrm{mg} \cdot \mathrm{L}^{-1}$ paclobutrazol, and $235 \mathrm{mg} \cdot \mathrm{L}^{-1}$ magnesium and $10 \mathrm{mg} \cdot \mathrm{L}^{-1}$ iron. Error bars represent $95 \%$ confidence intervals based on Tukey's honestly significant difference at $\alpha=\mathbf{0 . 0 5}$ analyzed by date; $1 \mathrm{ppm}=1 \mathrm{mg} \cdot \mathrm{L}^{-1}, 1 \mathrm{~cm}=0.3937$ inch. plants not receiving PGR $[P \leq 0.05$ (Fig. 3B)]. Trends were similar for canopy width as shown in Fig. 3C, where canopy width remained lowest for plants supplied with PGR starting at $2 \mathrm{l} \mathrm{d}$ into the consumer phase. The effect on plant form is very apparent in representative photos of plants within each treatment over time (Fig. 4 ), whereby lodging (weak, elongated foliage with open spaces between flowers) was very apparent in plants that did not receive PGR, regardless of fertilizer level.

At the end of the consumer phase, plants supplied PGR at the end of production had lower shoot dry weights compared with those supplied without PGR [WSF and WSF400 ( $P$ $\leq 0.05)$ ], with no effects on flower number (Table 5 ). Shoot tissue $\mathrm{N}$ was also lowest for plants irrigated with PGR before the consumer phase (Table 5), and all fertilizer and PGR strategies resulted in shoot tissue $\mathrm{N}$ below range recommended for petunia

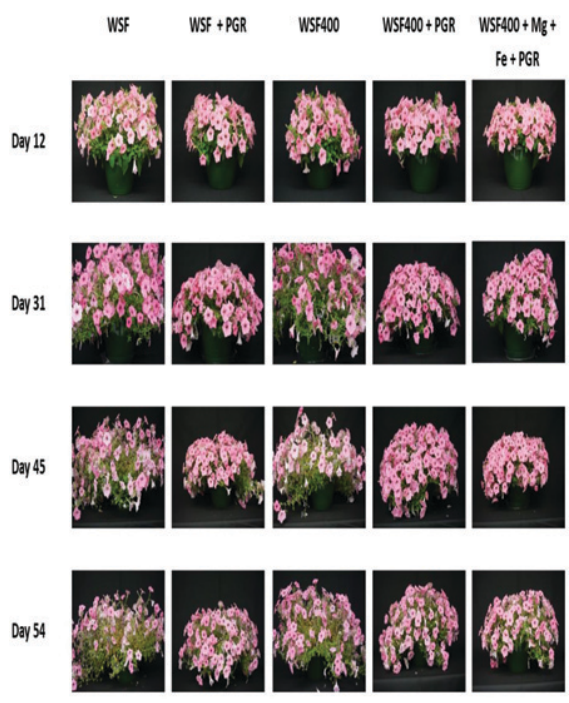

Fig. 4. Photographs from Expt. 2 for each combination of the one-time application of water-soluble fertilizer at 200 (WSF) or $400 \mathrm{mg} \cdot \mathrm{L}^{-1} \mathrm{~N}$ (WSF400), with no PGR or a 3 mg. $\mathrm{L}^{-1}$ paclobutrazol (“+ PGR"), and with WSF400 + PGR + magnesium $(\mathrm{Mg})+$ iron $(\mathrm{Fe})$ (including 235 $\mathrm{mg} \cdot \mathrm{L}^{-1} \mathrm{Mg}$ and $\left.10 \mathrm{mg} \cdot \mathrm{L}^{-1} \mathrm{Fe}\right)$ during the consumer phase for 'Supertunia Vista Bubblegum' petunia after increasing duration of irrigating with clear water. Photos within each row (day) are taken at the same distance from containers, but scale changes over time, and plants were randomly selected within each treatment during each date; $1 \mathrm{ppm}=1 \mathrm{mg} \cdot \mathrm{L}^{-1}$. 
Table 5. Water-soluble fertilizer (WSF) and plant growth regulator (PGR) treatment effects on shoot dry weight, flower number, shoot tissue nitrogen $(N)$, and $\mathrm{N}$ accumulated in shoot tissue at $63 \mathrm{~d}$ into the consumer phase for 'Supertunia Vista Bubblegum' petunia in Expt. 2.

\begin{tabular}{lcccc}
\hline Treatment code $^{\mathrm{z}}$ & $\begin{array}{c}\text { Shoot dry wt } \\
(\mathrm{g} / \text { plant })^{\mathrm{y}}\end{array}$ & $\begin{array}{c}\text { Flowers } \\
(\text { no./plant })\end{array}$ & $\begin{array}{c}\text { Tissue } \mathbf{N} \\
(\%)\end{array}$ & $\begin{array}{c}\mathbf{N} \text { accumulated in shoot } \\
\text { tissue }(\mathbf{m g} / \text { plant })^{\mathrm{y}}\end{array}$ \\
\hline WSF & $120.6 \mathrm{~b}^{\mathrm{x}}$ & $154 \mathrm{a}$ & $0.79 \mathrm{~b}$ & $952.6 \mathrm{a}$ \\
WSF400 & $123.7 \mathrm{~b}$ & $190 \mathrm{a}$ & $0.83 \mathrm{~b}$ & $1022.1 \mathrm{a}$ \\
WSF + PGR & $100.1 \mathrm{a}$ & $195 \mathrm{a}$ & $1.05 \mathrm{a}$ & $1053.2 \mathrm{a}$ \\
WSF400 + PGR & $102.2 \mathrm{a}$ & $214 \mathrm{a}$ & $1.13 \mathrm{a}$ & $1150.7 \mathrm{a}$ \\
WSF400 + & $103.2 \mathrm{a}^{\mathrm{x}}$ & $218 \mathrm{a}$ & $1.12 \mathrm{a}$ & $1155.8 \mathrm{a}$
\end{tabular}

$\mathrm{MgFe}+\mathrm{PGR}$

$\overline{{ }^{\mathrm{z}} \mathrm{WSF}}=17.0 \mathrm{~N}-1.8 \mathrm{P}-14.1 \mathrm{~K}$ water-soluble fertilizer; $\mathrm{PGR}=$ plant growth regulator; $\mathrm{MgFe}=$ magnesium and iron.

${ }^{\mathrm{y}} 1 \mathrm{~g}=0.0353 \mathrm{oz} ; 1 \mathrm{mg}=3.5274 \times 10^{-5} \mathrm{oz}$.

${ }^{x}$ Data represent least square means of eight replicates, and mean separation used Tukey's honestly significant difference at $\alpha=0.05$. Means with the same lowercase letter are not significantly different.

[3.85\% to $7.60 \% \mathrm{~N}$ (Gibson et al., 2007)]. There were no differences in accumulated shoot tissue $\mathrm{N}$ at the end of the consumer phase (Table 5 ).

\section{Conclusions}

Fertilizer and PGR strategies used during production have carry over effects on the performance of container crops, and these methods have potential to add value, differentiate plant products, and increase consumer success. Providing a residual fertilizer charge and plant growth regulator at the point of sale can increase plant performance for long-term and vigorous plants such as petunia in hanging baskets, patio containers, or the landscape.

Container-grown petunia that received CRF (incorporated or topdressed) or DCT and were topdressed with composted poultry litter maintained the greatest plant quality compared with the other fertilizer treatments, and they were still vigorously growing after $42 \mathrm{~d}$ in the consumer phase. Irrigating with high rates of WSF with supplemental $\mathrm{Mg}$ and $\mathrm{Fe}$ before sale provided some additional $\mathrm{N}$ and consumer benefit, but plants quickly became stunted and nutrient-deficient post-production. Except for composted poultry litter, organic or urea-based SRF applications resulted either in deficiency from slow nutrient release or phytotoxicity, probably from excessive urea$\mathrm{N}$. These results highlight the importance of providing continual and adequate rates of nutrient release when selecting residual fertilizer strategies for vigorous floriculture crop species.
Irrigating with the PGR paclobutrazol at the end of production extended petunia shelf life performance by maintaining plant form, as well as reducing plant growth rate and corresponding demand for nutrients. Growers have access to a range of PGR options and application methods, and combining effective PGR and residual fertilizer strategies has potential to further increase the duration of plant performance for the consumer. Selection of an appropriate combination of residual fertilizer and PGR strategy would likely depend on grower practicality and cost.

\section{Literature cited}

Broschat, T.K. and K.K. Moore. 2007. Release rates of ammonium-nitrogen, nitratenitrogen, phosphorus, potassium, magnesium, iron, and manganese from seven controlled-release fertilizers. Commun. Soil Sci. Plant Anal. 38:843-850, doi: $10.1080 / 00103620701260946$.

Burnett, S.E., N.S. Mattson, and K.A. Williams. 2016. Substrates and fertilizers for organic container production of herbs, vegetables, and herbaceous ornamental plants grown in greenhouse in the United States. Scientia Hort. 208:111-119, doi: 10.1016/j.scienta.2016.01.001.

Cabrera, R.I. 1997. Comparative evaluation of nitrogen release patterns from controlled-release fertilizer by nitrogen leaching analysis. HortScience 32:669-673, doi: 10.21273/HORTSCI.32.4.669.

Carson, L.C. and M. Ozores-Hampton. 2012. Methods for determining nitrogen release from controlled-release fertilizers used for vegetable production. HortTechnology 22:20-24, doi: 10.21273/HORTTECH.22.1.20.
Davis, T.D. 1991. Post-production performance of uniconazole-treated zinnia and marigold plugs. HortTechnology 1:49-52, doi: 10.21273/HORTTECH.1.1.49.

Fan, X.H. and Y.C. Li. 2010. Nitrogen release from slow-release fertilizers as affected by soil type and temperature. J. Soil Fert. Plant Nutr. 74:1635-1641, doi: 10.2136/sssaj2008.0363.

Fisher, P. 2003. Managing $\mathrm{pH}$ for container media, p. 39-45. In: D. Hamrick (ed.). Ball redbook: Crop production. 17th ed. Ball Publ., Batavia, IL.

Gibson, J.L., D.S. Pitchay, A.L. WilliamsRhodes, B.E. Whipker, P.V. Nelson, and J.M. Dole. 2007. Nutrient deficiencies in bedding plants. Ball Publ., Batavia, IL.

Guertal, E.A. 2009. Slow-release nitrogen fertilizer in vegetable production: A review. HortTechnology 19:16-19, doi: 10.21273/HORTSCI.19.1.16.

Keever, G.J. and J.R. Kessler. 2008. Paclobutrazol effects on bedding plants during production, shipping, and the retail environment when applied in production. J. Environ. Hort. 26:123-127, doi: 10.24266/ 0738-2898-26.2.123.

Latimer, J.G. 1991. Growth retardants affect landscape performance of zinnia, impatiens, and marigold. HortScience 26:557-560, doi: 10.21273/HORTSCI.26.5.557.

Latimer, J.G. and S.A. Baden. 1994. Persistent effects of plant growth regulators on landscape performance of seed geraniums. J. Environ. Hort. 26:150-154, doi: 10.24266/0738-2898-12.3.150.

Latimer, J.G. and B. Whipker. 2012. Selecting and using plant growth regulators on floricultural crops. Virginia Coop. Ext. Publ. 430-102.

Li, Y. and N.S. Mattson. 2019. Effect of organic fertilizer source and rate on growth and nutrient leachate profile of greenhouse-grown cucumber. HortTechnology 29:450-456, doi: 10.21273/ HORTTECH04293-19.

Million, J.B., J.E. Barrett, T.A. Nell, and D.G. Clark. 2002. One-time vs. continuous application of paclobutrazol in subirrigation water for the production of bedding plants. HortScience 37:345-347, doi: 10.21273/HORTSCI.37.2.345.

Mills, H.A. and J.B. Jones, Jr. 1996. Plant analysis handbook II: A practical sampling, preparation, analysis, and interpretation guide. MicroMacro Publ., Athens, GA.

Nelson, P.V. 2011. Greenhouse operation and management. 7th ed. Prentice Hall, Upper Saddle River, NJ.

Oliveira, S.F., P.R. Fisher, J. Huang, and S.C. Mello. 2016. Strategies to 
provide fertilizer for both production and consumer phases of petunia. HortTechnology 26:164-175, doi: 10.21273/ HORTTECH.26.2.164.

Purcell, L.C. and C.A. King. 1996. Total nitrogen determination in plant material by persulfate digestion. Agron. J. 88:111-113.
Ruter, J.M. 1996. Paclobutrazol application method influences growth and flowering of 'New Gold' lantana. HortTechnology 6:19-20, doi: 10.21273/ HORTTECH.6.1.19.
Sparks, B.D. 2020. State of the greenhouse industry: Top business concerns by region. 23 Oct. 2020 . <https://www. greenhousegrower.com/management/ state-of-the-greenhouse-industry-topbusiness-concerns-by-region/ $>$. 